\title{
Klimat a ochrona gruntów rolnych i leśnych przy ustalaniu lokalizacji inwestycji w oparciu o przepisy ogólne na obszarach nieobjętych miejscowym planem zagospodarowania przestrzennego
}

\section{Wprowadzenie}

Zmiany klimatu utożsamiane w szczególności z globalnym ociepleniem są wskazywane jako największe zagrożenie humanitarne, ekonomiczne i ekologiczne dla współczesnego świata, a to dlatego, że powodują m.in. podnoszenie się poziomu wód, erozję wybrzeży, susze, powodzie, pożary lasów ${ }^{1}$. Globalne ocieplenie obserwowane od połowy XX w. spowodowane jest - jak wynika z piątego raportu oceniającego opracowanego przez Międzyrządowy Zespół ds. Zmian Klimatu - głównie wzrostem stężenia gazów cieplarnianych emitowanych z działalności człowieka. Jako przyczynę tego wzrostu wskazuje się, obok spalania paliw kopalnych, również zmiany w zakresie użytkowania gruntów ${ }^{2}$. Grunty rolne wciąż wykorzystuje się bowiem pod budowę miast oraz obiektów handlowych i przemysłowych. Zauważa się przy tym, że europejskie obszary miejskie rozrastają się, a w związku z tym, coraz większe obszary gruntów rolnych pokrywane są betonem i asfaltem, co utrudnia, a często uniemożliwia m.in. magazynowanie wody, produkowanie żywności czy regulowanie klimatu ${ }^{3}$.

Mając na uwadze powyższe, rozważenia wymaga, czy obowiązujące regulacje normatywne stanowiące podstawę dla przeznaczania gruntów pod zabudowę, chronią grunty rolne i leśne, a przez to klimat. Zauważyć należy przy tym, że przedmiot

\footnotetext{
1 Zob. D. Dobrowolski, Świat a zmiany klimatyczne, https://globalna.ceo.org.pl/wiedza-o-spoleczenstwie-geografia-biologia/artykuly/swiat-zmiany-klimatyczne [dostęp: 12.05.2021]; P. Zielińska, Rozwój unijnych uregulowań prawnych w zakresie klimatu [w:] Unia Europejska wobec wyzwań przeszłości. Aspekty społeczne, gospodarcze i środowiskowe, red. E. Małuszyńska, P. Idczak, G. Mazur, Poznań 2015, s. 232. Por. też: J. Ciechanowicz-McLean, Prawo ochrony klimatu, Warszawa 2016, s. 82.

2 H. Bruyninckx, Sygnały EEA. Życie w zmieniającym się klimacie, s. 4, https://www.eea.europa.eu/pl/ publications/sygnaly-eea-2015-zycie-w [dostęp: 12.05.2021].

3 H. Bruyninckx, Sygnały EEA, Grunty i gleby: w kierunku zrównoważonego gospodarowania tymi niezbędnymi zasobami, s. 5, https://www.eea.europa.eu/www/pl/publications/sygnaly-eea-2019-grunty-i [dostęp: 12.05.2021].
} 
rozważań ujętych w niniejszym artykule ogranicza się do przypadków, gdy na danym terenie nie obowiązuje miejscowy plan zagospodarowania przestrzennego, a warunki zabudowy i zagospodarowania terenu ustalane są na podstawie tzw. porządku ustawowego, czyli w sytuacji, gdy gminy nie mogą swobodnie kształtować przeznaczenia terenów na swoim obszarze ${ }^{4}$. Zaznaczyć należy również, że analiza obejmuje wyłącznie przepisy ogólne w tym zakresie ujęte w ustawie z dnia 27 marca 2003 r. o planowaniu i zagospodarowaniu przestrzennym ${ }^{5}$, gdyż z zakresu niniejszego opracowania wyłączono regulacje ujęte $w$ tzw. specustawach inwestycyjnych ${ }^{6}$.

\section{Pojęcie gruntów rolnych i leśnych}

Definicje gruntów rolnych i leśnych zostały wprowadzone do - stanowiącej zasady w zakresie ochrony tych gruntów - ustawy z dnia z dnia 3 lutego 1995 r. o ochronie gruntów rolnych i leśnych ${ }^{7}$.

I tak, gruntami rolnymi są grunty: 1) określone w ewidencji gruntów jako użytki rolne; 2) pod stawami rybnymi i innymi zbiornikami wodnymi, służącymi wyłącznie dla potrzeb rolnictwa; 3) pod wchodzącymi w skład gospodarstw rolnych budynkami mieszkalnymi oraz innymi budynkami i urządzeniami służącymi wyłącznie produkcji rolniczej oraz przetwórstwu rolno-spożywczemu; 4) pod budynkami i urządzeniami służącymi bezpośrednio do produkcji rolniczej uznanej za dział specjalny, stosownie do przepisów o podatku dochodowym od osób fizycznych i podatku dochodowym od osób prawnych; 5) parków wiejskich oraz pod zadrzewieniami i zakrzewieniami śródpolnymi, w tym również pod pasami przeciwwietrznymi i urządzeniami przeciwerozyjnymi; 6) rodzinnych ogrodów działkowych i ogrodów botanicznych; 7) pod urządzeniami: melioracji wodnych, przeciwpowodziowych i przeciwpożarowych, zaopatrzenia rolnictwa w wodę, kanalizacji oraz utylizacji ścieków i odpadów dla potrzeb rolnictwa i mieszkańców wsi; 8) zrekultywowane dla potrzeb rolnictwa; 9) torfowisk i oczek wodnych; 10) pod drogami dojazdowymi do gruntów rolnych ${ }^{8}$. Mając na uwadze powyższe, wskazać należy, że grunt jest użytkiem rolnym wówczas, gdy jako taki został określony w ewidencji gruntów ${ }^{9}$. W orzecznictwie sądowoadministracyjnym wskazuje się bowiem, że dane z ewidencji gruntów są wiążące w zakresie

\footnotetext{
4 Na temat swobody planistycznej organów gminy w tym zakresie zob. K. Małysa-Sulińska, Prawo do dobrego samorządu a tryby ustalania lokalizacji inwestycji [w:] Prawo do dobrego samorzqdu w kontekście realizacji zadań publicznych, red. eadem, M. Stec, Warszawa 2021, s. 44 i n.

5 Dz. U. z 2021 r., poz. 741 ze zm. (dalej: u.p.z.p.).

6 Na temat regulacji ujętych w specustawach inwestycyjnych zob.: K. Małysa-Sulińska, Postępowania w sprawach inwestycyjno-budowlanych prowadzone w oparciu o regulacje szczególne ujęte w specustawach inwestycyjnych [w:] System administracyjnego prawa procesowego, red. A. Matan, G. Łaszczyca, t. 4, Warszawa 2021.

7 Dz. U. z 2021 r., poz. 1326 (dalej: u.g.r.l.).

8 Zob. art. 2 ust. 1 u.g.r.l.

9 Por. K. Małysa, Ustalanie warunków zabudowy i zagospodarowania terenu dla gruntów rolnych, "Samorząd Terytorialny" 2003, nr 11, s. 25.
} 
ich rolniczego charakteru ${ }^{10}$. Do użytków rolnych zalicza się zaś: grunty orne, sady, łąki trwałe, pastwiska trwałe, grunty rolne zabudowane, grunty pod stawami, grunty pod rowami oraz grunty zadrzewione i zakrzewione na użytkach rolnych ${ }^{11}$. Z uwagi na ograniczenia objętościowe niniejszego tekstu niemożliwa jest analiza poszczególnych rodzajów gruntów rolnych, przy czym wskazać należy, że wyliczenie ujęte w art. 2 ust. 1 u.g.r.l. częściowo jest zbędne, gdyż poszczególne jego elementy zawierają się w zakresie przedmiotowym objętym pkt $1^{12}$.

Gruntami leśnymi są zaś grunty: 1) określone jako lasy w przepisach o lasach; 2) zrekultywowane dla potrzeb gospodarki leśnej; 3) pod drogami dojazdowymi do gruntów leśnych ${ }^{13}$. Mając na uwadze powyższe, a także ograniczenia objętościowe niniejszego tekstu zasygnalizować należy wyłącznie, że jako las ustawodawca definiuje ${ }^{14}$ nie tylko grunt o zwartej powierzchni co najmniej 0,10 ha, pokryty roślinnością leśną (uprawami leśnymi) - drzewami i krzewami oraz runem leśnym - lub przejściowo jej pozbawiony: przeznaczony do produkcji leśnej lub stanowiący rezerwat przyrody lub wchodzący w skład parku narodowego albo wpisany do rejestru zabytków, ale także grunt związany z gospodarką leśną, zajęty pod wykorzystywane dla potrzeb gospodarki leśnej: budynki i budowle, urządzenia melioracji wodnych, linie podziału przestrzennego lasu, drogi leśne, tereny pod liniami energetycznymi, szkółki leśne, miejsca składowania drewna, a także wykorzystywany na parkingi leśne i urządzenia turystyczne ${ }^{15}$.

Natomiast - jak wskazano w art. 2 ust. 3 u.g.r.l. - nie uważa się za grunty rolne gruntów znajdujących się pod parkami i ogrodami wpisanymi do rejestru zabytków ${ }^{16}$. Należy podkreślić, że wpisanie lasu do rejestru zabytków nie pozbawia go prawnego charakteru lasu, co oznacza, że las wpisany do rejestru zabytków jest gruntem leśnym w rozumieniu ustawy o ochronie gruntów ${ }^{17}$.

\section{Tryby ustalania lokalizacji inwestycji na gruntach rolnych i leśnych}

Tryb ustalenia lokalizacji inwestycji w Polsce determinowany jest rodzajem planowanego przedsięwzięcia. Poza ogólnymi regulacjami z tego zakresu ujętymi w szczególności w przepisach upzp, ustawodawca wprowadził bowiem - w odniesieniu do szerokiej grupy inwestycji, których realizację uznano za istotną, a często również pożądaną

10 Zob. wyrok NSA z dnia 25 sierpnia 1989 r., SA/Wr 1168/88, ONSA 1989, nr 2, poz. 78.

11 Zob. § 68 ust. 1 pkt 1 rozporządzenia Ministra Rozwoju Regionalnego i Budownictwa z dnia 29 marca 2001 r. w sprawie ewidencji gruntów i budynków (Dz. U. z 2019 r., poz. 393; dalej: r.e.g.b.).

12 Szerzej na ten temat zob. W. Radecki, Ustawa o ochronie gruntów rolnych i leśnych. Komentarz, Warszawa 2012, LEX/el., art. 2; autor dokonał szczegółowej analizy zakresu przedmiotowego objętego art. 2 u.g.r.l.

13 Zob. art. 2 ust. 2 u.g.r.l.

14 Zob. art. 3 ustawy z dnia 28 września 1991 r. o lasach (Dz. U. z 2021 r., poz. 1275 ze zm.).

15 Szerzej na temat gruntów definiowanych jako leśne w rozumieniu przepisów u.g.r.l. zob. W. Radec-

ki, Ustawa..., LEX/el., art. 2.

16 Zob. art. 2 ust. 3 u.g.r.l.

17 Szerzej na ten temat zob.: W. Radecki, Ustawa..., LEX/el., art. 2. 
dla prawidłowego rozwoju naszego kraju - regulacje szczególne zawarte w tzw. specustawach inwestycyjnych ${ }^{18}$. Uwzględniając przedmiot niniejszego artykułu, zauważyć należy, że w odniesieniu do gruntów rolnych i leśnych objętych decyzją lokalizacyjną procedowaną w oparciu o przepisy tzw. specustaw inwestycyjnych, zasadniczo wyłączone jest stosowanie przepisów uogrl ${ }^{19}$. Oznacza to, że ustawodawca dopuszcza lokalizację na gruntach rolnych i leśnych inwestycji podlegających regulacjom specprzepisów, choć czyni w tym zakresie również wyjątki ${ }^{20}$.

Mając zaś na uwadze - ujęte w przepisach u.p.z.p. - regulacje ogólne z tego zakresu, wskazać należy, że ustalenie przeznaczenia terenu, rozmieszczenie inwestycji celu publicznego oraz określenie sposobów zagospodarowania i warunków zabudowy terenu następuje w miejscowym planie zagospodarowania przestrzennego ${ }^{21}$. W tych aktach prawa miejscowego ${ }^{22}$ ustala się m.in. linie rozgraniczające tereny o różnym przeznaczeniu lub różnych zasadach zagospodarowania ${ }^{23}$, a także zasady kształtowania zabudowy oraz wskaźniki zagospodarowania terenu, maksymalną i minimalną intensywność zabudowy, minimalny udział procentowy powierzchni biologicznie czynnej, maksymalną wysokość zabudowy, minimalną liczbę miejsc do parkowania oraz linie zabudowy i gabaryty obiektów ${ }^{24}$. Zauważenia wymaga jednak, że przeznaczenie w planie miejscowym gruntów rolnych i leśnych na cel nierolniczy i nieleśny może wiązać się z koniecznością uzyskania przez - sporządzającego projekt tego aktu prawa

\footnotetext{
18 Szerzej na temat tzw. specustaw inwestycyjnych zob.: K. Małysa-Sulińska, Postępowania..., 406 i n. 19 Zob. np.: art. 9yc ust. 1 ustawy z dnia 28 marca 2003 r. o transporcie kolejowym (Dz. U. z 2020 r., poz. 1043 ze zm.); art. 21 ust. 1 ustawy z dnia 10 kwietnia 2003 r. o szczególnych zasadach przygotowania i realizacji inwestycji w zakresie dróg publicznych (Dz. U. z 2020 r., poz. 1363 ze zm.); art. 24h ust. 1 ustawa z dnia 7 września 2007 r. o przygotowaniu finałowego turnieju Mistrzostw Europy w Piłce Nożnej UEFA EURO 2012 (Dz. U. z 2020 r., poz. 2008); art. 17 ustawy z dnia 12 lutego 2009 r. o szczególnych zasadach przygotowywania i realizacji inwestycji w zakresie lotnisk użytku publicznego (Dz. U. z 2021 r., poz. 1079).

20 Zob. art. 7 ust. 3 ustawy z dnia 5 lipca 2018 r. o ułatwieniach w przygotowaniu i realizacji inwestycji mieszkaniowych oraz inwestycji towarzyszących (Dz. U. z 2020 r., poz. 219 ze zm.; dalej: specustawa mieszkaniowa), zgodnie z którym inwestycji mieszkaniowych - w trybie przewidzianym w tej ustawie - nie można lokalizować na terenach wymagających uzyskania zgody na przeznaczenie gruntów rolnych poza granicami administracyjnymi miast na cele nierolnicze, wynikającej z przepisów o ochronie gruntów rolnych i leśnych.

21 Zob. art. 4 ust. 1 u.p.z.p.

22 Zob. art. 14 ust. 8 u.p.z.p.

23 Por. art. 15 ust. 2 pkt 1 u.p.z.p. Zob. też $\S 4$ pkt 1 rozporządzenia Ministra Infrastruktury z dnia 26 sierpnia $2003 \mathrm{r}$. w sprawie wymaganego zakresu projektu miejscowego planu zagospodarowania przestrzennego (Dz. U. Nr 164, poz. 1587; dalej: rozp. m.p.z.p.), zgodnie z którym - zawarte w projekcie tekstu miejscowego planu zagospodarowania przestrzennego - ustalenia dotyczące przeznaczenia terenów powinny zawierać określenie przeznaczenia poszczególnych terenów lub zasad ich zagospodarowania, a także symbol literowy i numer wyróżniający go spośród innych terenów.

24 Por. art. 15 ust. 2 pkt 6 u.p.z.p. Zob. też $\$ 4$ pkt 6 rozp. m.p.z.p., zgodnie z którym - zawarte w projekcie tekstu miejscowego planu zagospodarowania przestrzennego - ustalenia dotyczące parametrów i wskaźników kształtowania zabudowy oraz zagospodarowania terenu powinny zawierać w szczególności określenie linii zabudowy, wielkości powierzchni zabudowy w stosunku do powierzchni działki lub terenu, w tym udziału powierzchni biologicznie czynnej, a także gabarytów i wysokości projektowanej zabudowy oraz geometrii dachu.
} 
miejscowego - wójta (burmistrza lub prezydenta miasta) - zgody innego organu na takie przeznaczenie ${ }^{25}$. W przypadku gruntów o najwyższej przydatności produkcyjnej czyli gruntów rolnych klas bonitacyjnych $1-1 \mathrm{II}^{26}$ oraz gruntów leśnych ustawodawca dopuszcza bowiem zmianę ich przeznaczenia, ale na zasadzie wyjątku ${ }^{27}$. Przy dokonywaniu tej zmiany należy rozważyć zarówno interes publiczny, jakim jest ochrona gruntów rolnych i leśnych, jak również interes gminy wnioskującej o zamianę tego przeznaczenia w związku z podjęciem procedury planistycznej ${ }^{28}$.

Ustalenia ujęte w miejscowym planie zagospodarowania przestrzennego - w przypadku inwestycji lokalizowanych na zasadach ogólnych ${ }^{29}$ - stanowią podstawę kształtowania władczych rozstrzygnięć np. w decyzji o pozwoleniu na budowę $e^{30}$. Sporządzenie planu miejscowego co do zasady nie jest jednak obligatoryjne ${ }^{31}$, a w związku z tym - duża część naszego kraju nie podlega ustaleniom tych aktów prawa miejscowego. W przypadku terenów niepodlegających ustaleniom obowiązującego miejscowego planu zagospodarowania przestrzennego, ustalenie sposobów zagospodarowania i warunków zabudowy terenu zasadniczo ${ }^{32}$ następuje w formie decyzji ustalającej warunki zabudowy i zagospodarowania terenu. Decyzja ta przybiera postać decyzji

25 Zob. art. 7 ust. 2 u.g.r.l., w którym wskazano, że przeznaczenie na cele nierolnicze i nieleśne: (pkt 1) gruntów rolnych stanowiących użytki rolne klas I-III wymaga uzyskania zgody ministra właściwego do spraw rozwoju wsi, z zastrzeżeniem art. 7 ust. 2a; (pkt 2) gruntów leśnych stanowiących własność Skarbu Państwa - wymaga uzyskania zgody ministra właściwego do spraw środowiska lub upoważnionej przez niego osoby; (pkt 5) pozostałych gruntów leśnych - wymaga uzyskania zgody marszałka województwa wyrażanej po uzyskaniu opinii izby rolniczej.

26 Zauważenia wymaga jednak, że - zgodnie z art. 10a u.g.r.l. - przepisów rozdziału 2 u.g.r.l. zatytułowanego Ograniczanie przeznaczania gruntów na cele nierolnicze i nieleśne nie stosuje się do gruntów rolnych położonych w granicach administracyjnych miast.

27 Por. wyrok NSA z dnia 8 grudnia 2020 r., II OSK 1993/18, LEX nr 3095638.

28 Por. wyrok NSA z dnia 2 września 2014 r., II OSK 436/13, LEX nr 1572729.

29 Inne rozwiązania $w$ tym zakresie przyjęto $w$ specustawach inwestycyjnych (zob. np. art. 5 ust. 3 specustawy mieszkaniowej, w którym wskazano, że inwestycję mieszkaniową lub inwestycję towarzyszącą realizuje się niezależnie od istnienia lub ustaleń miejscowego planu zagospodarowania przestrzennego, pod warunkiem że nie jest sprzeczna ze studium uwarunkowań i kierunków zagospodarowania przestrzennego gminy oraz uchwałą o utworzeniu parku kulturowego).

30 Zob. art. 35 ust. 1 pkt. 1 lit. a, ust. 4 i ust. 3 w zw. z ust. 5 pkt 1 ustawy z dnia 7 lipca 1994 r. - Prawo budowlane (Dz. U. z 2020 r., poz. 1333 ze zm.).

31 Zob. art. 14 ust. 7 u.p.z.p., w którym wskazano, że miejscowy plan zagospodarowania przestrzennego sporządza się obowiązkowo wyłącznie wówczas, gdy wymagają tego przepisy. Przepisem takim jest np. art. 5 ust. 1 ustawy z dnia 7 maja 1999 r. o ochronie terenów byłych hitlerowskich obozów zagłady (Dz. U. z 2015 r., poz. 2120, zgodnie z którym gmina ma obowiązek sporządzenia planu miejscowego dla obszaru Pomnika Zagłady i jego strefy ochronnej, przy czym - jak wskazano w art. 4 ust. 3 tej ustawy - granice tego obszaru i jego strefy ochronnej określa w rozporządzeniu minister właściwy do spraw kultury i ochrony dziedzictwa narodowego po zasięgnięciu opinii właściwego terytorialnie wójta (burmistrza lub prezydenta miasta).

32 Zob. jednak art. 50 ust. 2 oraz art. 59 ust. 1 i 2 u.p.z.p., w których wskazano wyjątki od obowiązku uzyskania decyzji ustalającej warunki zabudowy i zagospodarowania terenu (na ten temat: Planowanie i zagospodarowanie przestrzenne. Komentarz, red. Z. Niewiadomski, K. Jaroszyński, A. Szmytt, Ł. Złakowski, Warszawa 2011, s. 392 i n. oraz s. 481 i n.; A. Despot-Mładanowicz [w:] Ustawa o planowaniu i zagospodarowaniu przestrzennym. Komentarz, red. M. Wierzbowski, A. Plucińska-Filipowicz, Warszawa 2016, s. 547 i n. oraz s. 603 i n. 
o ustaleniu lokalizacji inwestycji celu publicznego ${ }^{33}$ lub decyzji o ustaleniu warunków zabudowy ${ }^{34}$, przy czym tryb postępowania i rodzaj rozstrzygnięcia determinowany jest możliwością kwalifikacji przedsięwzięcia jako inwestycji celu publicznego ${ }^{35}$. Przedmiotowa decyzja lokalizacyjna powinna zawierać w szczególności elementy wskazane w art. 54 u.p.z.p. czyli określać rodzaj inwestycji, warunki i szczegółowe zasady zagospodarowania terenu oraz jego zabudowy wynikające z przepisów odrębnych, a także linie rozgraniczające teren inwestycji ${ }^{36}$. W związku z przedmiotem rozstrzygnięcia, decyzje o warunkach zabudowy i zagospodarowania terenu są postrzegane jako surogat miejscowego planu zagospodarowania przestrzennego ${ }^{37}$. Podobnie jak plan miejscowy są one wiążące dla organów wydających rozstrzygnięcie w przedmiocie pozwolenia na budowę ${ }^{38}$, a w związku z tym stanowią dla adresata prawnie wiążące i skuteczne erga omnes potwierdzenie możliwości zagospodarowania terenu w określony sposób ${ }^{39}$.

Zauważenia wymaga przy tym, że wydanie wskazanych powyżej decyzji określających warunki zabudowy i zagospodarowania terenu determinowane jest spełnieniem przesłanek określonych przez ustawodawcę, przy czym nie są one tożsame w obydwu omawianych trybach lokalizacyjnych. Wydanie decyzji o warunkach zabudowy jest bowiem możliwe w przypadku łącznego spełnienia przesłanek określonych w kolejnych punktach art. 61 ust. 1 u.p.z.p. Oznacza to, że co do zasady ${ }^{40}$ przedmiotowa decyzja

\footnotetext{
33 Zob. art. 4 ust. 2 pkt 1 u.p.z.p. (na temat tej decyzji zob.: M. Szewczyk [w:] Z. Leoński, M. Szewczyk, M. Kruś, Prawo zagospodarowania przestrzeni, Warszawa 2019, s. 365 i n.; K. Małysa-Sulińska, Administracyjnoprawne aspekty inwestycji budowlanych, Warszawa 2012, s. 46 i n.). Zob. także: M. Szewczyk, Lokalizacja inwestycji publicznych w świetle nowej ustawy o planowaniu i zagospodarowaniu przestrzennym, "Casus" 2003, nr 28, s. 6 i n.; K. Małysa-Sulińska, Zakres przedmiotowy przedsięwzięć, dla których warunki zabudowy i zagospodarowania terenu określane sq $w$ formie decyzji o ustaleniu lokalizacji inwestycji celu publicznego, "Casus" 2009, nr 53, s. 6 i n.

34 Zob. art. 4 ust. 2 pkt 2 u.p.z.p. (na temat tej decyzji zob.: M. Szewczyk [w:] Z. Leoński, M. Szewczyk, M. Kruś, Prawo..., s. 365 i n.; K. Małysa-Sulińska, Administracyjnoprawne..., s. 95 i n.).

35 Zgodnie z regulacją art. 2 pkt 5 u.p.z.p. pod pojęciem inwestycji celu publicznego należy rozumieć działania o znaczeniu lokalnym (gminnym) i ponadlokalnym (powiatowym, wojewódzkim i krajowym), a także krajowym (obejmującym również inwestycje międzynarodowe i ponadregionalne), oraz metropolitalnym (obejmującym obszar metropolitalny) bez względu na status podmiotu podejmującego te działania oraz źródła ich finansowania, stanowiące realizację celów, o których mowa w art. 6 ustawy z dnia 21 sierpnia 1997 r. o gospodarce nieruchomościami, Dz. U. z 2020 r., poz. 1990 ze zm. (dalej: u.g.n.). Szerzej na temat przesłanek kwalifikowania przedsięwzięcia jako inwestycji celu publicznego zob. K. Małysa-Sulińska, Zakres..., s. 6 i n.

36 Szerzej na temat treści decyzji ustalającej warunki zabudowy i zagospodarowania terenu zob. $\mathrm{K}$. Małysa-Sulińska, Administracyjnoprawne..., Warszawa 2012, s. 75 i n.

37 Szerzej na ten temat zob. M. Szewczyk [w:] Z. Leoński, M. Szewczyk, M. Kruś, Prawo..., s. 209 i n.

38 Zob. art. 55 u.p.z.p., w którym wskazano, że decyzja o ustaleniu lokalizacji inwestycji celu publicznego wiąże organ wydający decyzję o pozwoleniu na budowę, a przepis ten - zgodnie z regulacją art. 64 ust. 1 u.p.z.p. - stosuje się odpowiednio do decyzji o warunkach zabudowy.

39 Zob. M. Szewczyk [w:] Z. Leoński, M. Szewczyk, M. Kruś, Prawo..., s. 209-210.

40 Ustawodawca przewidział jednak wyjątki od tej zasady. Zob. art. 61 ust. 2 u.p.z.p., w którym wskazano, że przepisów art. 61 ust. 1 pkt 1 tej ustawy nie stosuje się do inwestycji produkcyjnych lokalizowanych na terenach przeznaczonych na ten cel w planach miejscowych, które utraciły moc na podstawie art. 67 ust. 1 u.z.p. Zob. również art. 61 ust. 3 u.p.z.p., zgodnie z którym przepisów art. 61 ust. 1
} 
lokalizacyjna może zostać wydana, gdy: 1) co najmniej jedna działka sąsiednia, dostępna z tej samej drogi publicznej, jest zabudowana w sposób pozwalający na określenie wymagań dotyczących nowej zabudowy w zakresie kontynuacji funkcji, parametrów, cech i wskaźników kształtowania zabudowy oraz zagospodarowania terenu, w tym gabarytów i formy architektonicznej obiektów budowlanych, linii zabudowy oraz intensywności wykorzystania terenu; 2) teren ma dostęp do drogi publicznej; 3) istniejące lub projektowane uzbrojenie terenu jest wystarczające dla zamierzenia budowlanego; 4) teren nie wymaga uzyskania zgody na zmianę przeznaczenia gruntów rolnych i leśnych na cele nierolnicze i nieleśne albo jest objęty zgodą uzyskaną przy sporządzaniu miejscowych planów, które utraciły moc na podstawie ustawy z dnia 7 lipca 1994 r. o zagospodarowaniu przestrzennym ${ }^{41}$; 5) decyzja jest zgodna z przepisami odrębnymi; 6) zamierzenie budowlane nie znajduje się w obszarze: a) w stosunku do którego decyzją o ustaleniu lokalizacji strategicznej inwestycji w zakresie sieci przesyłowej, o której mowa w art. 5 ust. 1 ustawy z dnia 24 lipca 2015 r. o przygotowaniu i realizacji strategicznych inwestycji w zakresie sieci przesyłowych, ustanowiony został zakaz, o którym mowa w art. 22 ust. 2 pkt 1 tej ustawy, b) strefy kontrolowanej wyznaczonej po obu stronach gazociągu, c) strefy bezpieczeństwa wyznaczonej po obu stronach rurociągu $^{42}$. Natomiast - jak wynika z regulacji ujętej w art. 50 ust. 1a oraz art. 56 zdanie pierwsze u.p.z.p. - wydanie decyzji o ustaleniu lokalizacji inwestycji celu publicznego zasadniczo determinowane jest spełnieniem wyłącznie dwóch z przywołanych powyżej przesłanek, gdyż art. 61 ust. 1 pkt 4, stosuje się odpowiednio w przedmiotowym postępowaniu lokalizacyjnym ${ }^{43}$, a - jak wskazano w art. 56 u.p.z.p. - nie można odmówić ustalenia lokalizacji inwestycji celu publicznego, jeżeli zamierzenie inwestycyjne jest zgodne z przepisami odrębnymi ${ }^{44}$. Zauważyć należy przy tym, że ustawodawca wprowadził wyjątek od wymogu spełnienia przesłanki, o której mowa w art. 61 ust. 1 pkt 4 u.p.z.p. wskazując, że przepisu tego nie stosuje się do inwestycji celu publicznego

pkt 1 i 2 tej ustawy nie stosuje się do linii kolejowych, obiektów liniowych i urządzeń infrastruktury technicznej, a także instalacji odnawialnego źródła energii w rozumieniu art. 2 pkt 13 ustawy z dnia 20 lutego 2015 r. o odnawialnych źródłach energii (Dz. U. z 2018 r., poz. 2389 ze zm.). Nadto zob. art. 61 ust. 4 u.p.z.p. stanowiący, że przepisów art. 61 ust. 1 pkt 1 tej ustawy nie stosuje się do zabudowy zagrodowej, w przypadku gdy powierzchnia gospodarstwa rolnego związanego z tą zabudową przekracza średnią powierzchnię gospodarstwa rolnego w danej gminie.

41 Dz. U. z 1999 r. Nr 15, poz. 139 ze zm.; dalej: u.z.p.

42 Wskazać trzeba, że przepis art. 61 ust. 1 pkt 6 u.p.z.p. obowiązuje od dnia 27 maja 2021 r., przy czym - zgodnie z art. 9 ust. 1 z dnia 20 kwietnia 2021 r. o zmianie ustaw regulujących przygotowanie i realizację kluczowych inwestycji w zakresie strategicznej infrastruktury energetycznej - do postępowań w sprawie wydania decyzji lokalizacyjnych wszczętych i niezakończonych przed dniem wejścia w życie niniejszej ustawy decyzją ostateczną, stosuje się przepisy u.p.z.p. w brzmieniu dotychczasowym. Na temat przesłanek ustalenia warunków zabudowy zob.: K. Małysa-Sulińska, Administracyjnoprawne..., s. 103 i n.; M. Szewczyk [w:] idem, Z. Leoński, M. Kruś, Prawo..., s. 399 i n. A. Despot-Mładanowicz [w:] Ustawa o planowaniu i zagospodarowaniu przestrzennym. Komentarz, red. idem, M. Wierzbowski, A. Plucińska-Filipowicz, K. Buliński et al., Warszawa 2016, s. 614 i n.

43 Zob. art. 50 ust. 1 zdanie pierwsze u.p.z.p.

44 Na temat przesłanek ustalenia lokalizacji inwestycji celu publicznego zob.: K. Małysa-Sulińska, Administracyjnoprawne..., s. 64 i n.; M. Szewczyk [w:] idem, Z. Leoński, M. Kruś, Prawo..., s. 396 i n. 
w przypadkach uzasadnionych potrzebami obronności lub bezpieczeństwa państwa albo ochrony granicy państwowej, a także do inwestycji celu publicznego z zakresu łączności publicznej ${ }^{45}$.

\section{Weryfikacja przesłanki wydania decyzji lokalizacyjnych, o której mowa w art. 61 ust. 1 pkt 4 u.p.z.p.}

Wydanie decyzji o lokalizacji inwestycji celu publicznego, jak również decyzji o warunkach zabudowy zasadniczo jest determinowane - jak to wskazano powyżej - spełnieniem przesłanki określonej $w$ art. 61 ust. 1 pkt 4 u.p.z.p. Z przepisu tego wynika, że ustawodawca dopuszcza lokalizację inwestycji w trybie jurysdykcyjnym prowadzonym w oparciu o przepisy ogólne u.p.z.p. na gruntach, które albo nie wymagają uzyskania zgody na zmianę przeznaczenia na cele nierolnicze i nieleśne, albo zostały objęte zgodą uzyskaną przy sporządzaniu miejscowych planów zagospodarowania przestrzennego, które utraciły moc na podstawie art. 67 u.z.p.

Powyższe oznacza, że przesłanka ta jest spełniona w odniesieniu do gruntów, które nie są kwalifikowane jako rolne lub leśne, przy czym - mając na uwadze przywołaną powyżej regulację art. 10a u.g.r.l. - jako takie należy traktować również wszystkie grunty rolne położone $w$ granicach administracyjnych miast. Wszystkie grunty rolne położone na obszarze miasta są bowiem - jak wskazuje się w orzecznictwie sądowoadministracyjnym - z mocy przywołanej powyżej ustawy gruntami odrolnionymi ${ }^{46}$.

Przedmiotowa przesłanka jest spełniona również $\mathrm{w}$ odniesieniu do gruntów rolnych klasy IV, IVa, IVb, V, VI, Vlz lub o nieoznaczonej klasie, nawet jeśli są położone poza granicami administracyjnymi miast. Jak bowiem wskazano $w$ art. 7 ust. 2 u.g.r.l, zgody na przeznaczenie na cele nierolnicze i nieleśne wymagają tylko grunty rolne klasy I-III oraz grunty leśne, przy czym ich przeznaczenie na cel nierolniczy i nieleśny zasadniczo może nastąpić wyłącznie w miejscowym planie zagospodarowania przestrzennego ${ }^{47}$.

Spośród - położonych poza granicami administracyjnymi miast - gruntów rolnych klasy I-III, zgody na zmianę przeznaczenia nie wymagają wyłącznie takie, w odniesieniu do których spełnione są łącznie ${ }^{48}$ cztery warunki wskazane $w$ art. 7 ust. 2a u.g.r.l.: 1) co najmniej połowa powierzchni każdej zwartej części gruntu zawiera się w obszarze zwartej zabudowy, przy czym rozumie się przez to obszar wyznaczony przez obwiednię prowadzoną w odległości $50 \mathrm{~m}$ od zewnętrznych krawędzi skrajnych budynków tworzących zwartą zabudowę lub po zewnętrznych granicach działek, na których położone są te budynki, jeśli ich odległość od tych granic jest mniejsza niż

\footnotetext{
45 Zob. art. 50 ust. 1 a u.p.z.p.

46 Zob. wyrok WSA w Białymstoku z dnia 23 listopada 2017 r., II SA/Bk 537/17, LEX nr 2404092.

47 Zob. art. 7 ust. 1 u.g.r.l.

48 Zob. wyrok WSA w Bydgoszczy z dnia 10 kwietnia 2020 r., II SA/Bd 66/20, LEX nr 3031156, w którym wskazano, że przepis art. 7 ust. 2a ustawy z 1995 r. o ochronie gruntów rolnych i leśnych wymaga łącznego spełnienia wszystkich wyszczególnionych w nim warunków, a nie wyłącznie części z nich.
} 
$50 \mathrm{~m}^{49}$; 2) położone są w odległości nie większej niż 50 m od granicy najbliższej działki budowlanej w rozumieniu przepisów u.g.n.; 3) położone są w odległości nie większej niż 50 m od drogi publicznej w rozumieniu przepisów ustawy z dnia 21 marca 1985 r. o drogach publicznych ${ }^{50}$, 4) ich powierzchnia nie przekracza 0,5 ha, bez względu na to, czy stanowią jedną całość, czy stanowią kilka odrębnych części ${ }^{51}$. Weryfikacja spełnienia powyższych warunków następuje w toku postępowania lokalizacyjnego, a ich pozytywne ustalenia w tym zakresie przez organ właściwy w przedmiocie ustalenia warunków zabudowy i zagospodarowania terenu oznaczają, że w konkretnej sprawie spełniona jest przesłanka wydania decyzji lokalizacyjnej, o której mowa w art. 61 ust. 1 pkt 4 u.p.z.p.

Przesłanka determinująca określenie warunków zabudowy i zagospodarowania terenu, o której mowa w art. 61 ust. 1 pkt 4 u.p.z.p., może być spełniona również wówczas, gdy grunt wymaga wprawdzie zgody na zmianę przeznaczenia na cel nierolniczy i nieleśny, ale zgoda ta została już raz wyrażona. Podkreślenia wymaga jednak, że przypadek ten obejmuje wyłącznie sytuacje, gdy wyrażenie zgody nastąpiło przy okazji sporządzania miejscowego planu zagospodarowania przestrzennego, który na danym terenie obowiązywał w dniu 1 stycznia 1995 r., a - w związku z regulacją ujętą w art. 67 u.z.p. - utracił moc obowiązującą bądź z dniem 31 grudnia 2002 r., bądź z dniem 31 grudnia 2003 r. $^{52}$ Zastrzec należy przy tym, że spełnienie tej przesłanki warunkowane jest "skonsumowaniem" udzielonej zgody na zmianę przeznaczenia gruntu rolnego lub leśnego na cele nierolnicze i nieleśne poprzez wprowadzenie stosownych zapisów do planu miejscowego. Oznacza to, że wydanie decyzji o warunkach zabudowy i zagospodarowania terenu na cel nierolny i nieleśny w odniesieniu do gruntów

\footnotetext{
$\overline{49}$ Zob. art. 4 pkt 30 u.g.r.l. Zob. również art. 4 pkt 29 u.g.r.l., w którym zdefiniowano zwartą zabudowę, wskazując, że rozumie się przez to zgrupowanie nie mniej niż 5 budynków, z wyjątkiem budynków o funkcji wyłącznie gospodarczej, pomiędzy którymi największa odległość sąsiadujących ze sobą budynków nie przekracza $100 \mathrm{~m}$.

50 Dz. U. z 2020 r., poz. 470 ze zm.

51 Szerzej na temat tych warunków zob.: J. Kaczor, Zmiana przeznaczenia gruntów rolnych klas I-III na podstawie art. 7 ust. 2 a ustawy o ochronie gruntów rolnych i leśnych, NZS 2017, nr 3, s. 37. Por. też: E. Klat-Górska, Ochrona gruntów rolnych w obszarach wiejskich [w:] Instytucje prawa rolnego, red. M. Korzycka, Warszawa 2019, LEX/el. Zob. też wyrok WSA w Gdańsku z dnia 20 lutego 2019 r., II SA/Gd 651/18, LEX nr 2628114, w którym wskazano, że skoro obwiednia ma być prowadzona w odległości $50 \mathrm{~m}$ albo od zewnętrznych krawędzi skrajnych budynków lub po zewnętrznych granicach działek na których położone są, to przyjąć należy, że w obszarze zwartej zabudowy mogą się znaleźć wyłącznie działki już zabudowane; zob. także wyrok WSA w Kielcach z dnia 4 marca 2021 r., II SA/Ke 41/21, LEX nr 3150787, zgodnie z którego uzasadnieniem dopiero prawidłowe ustalenie okoliczności umożliwiających weryfikację lokalizacji działki zainwestowanej w zwartej zabudowie stanowi punkt wyjścia do ustaleń mających na celu stwierdzenie, że przynajmniej połowa powierzchni każdej zwartej części gruntu zawiera się w obszarze zwartej zabudowy.

52 Podkreślenia wymaga, że zgodnie z wolą ustawodawcy określenie w decyzji lokalizacyjnej warunków zabudowy i zagospodarowania terenu na cel nierolny lub nieleśny dla gruntu rolnego lub leśnego nie jest dopuszczalne, jeśli omawiana zgoda została udzielona w związku ze sporządzaniem miejscowego planu zagospodarowania przestrzennego, który utracił moc w innych okolicznościach niż wskazane w art. 67 u.z.p., a to np. na skutek stwierdzenia jego nieważności (por. Planowanie i zagospodarowanie przestrzenne. Komentarz..., s. 525-526).
} 
wymagających uzyskania zgody, o której mowa art. 7 ust. 2 u.g.r.l. jest dopuszczalne wówczas, gdy równocześnie spełnione są dwie przesłanki: 1) wydana została decyzja wyrażająca zgodę na zmianę przeznaczenia gruntu rolnego lub leśnego na cel nierolniczy i nieleśny; 2) grunt ten został przeznaczony na cel nierolniczy i nieleśny w miejscowym planie zagospodarowania przestrzennego, który obowiązywał w dniu 1 stycznia 1995 r., a utracił moc obowiązującą na podstawie art. 67 u.z.p. W związku z powyższym, niedopuszczalne jest wydanie opisanej powyżej decyzji lokalizacyjnej z powołaniem się na okoliczność uzyskania zgody właściwego organu na zmianę przeznaczenia na cel nierolniczy i nieleśny, jeżeli w dniu 1 stycznia 1995 r. na danym terenie nie obowiązywał plan miejscowy lub obowiązujący wówczas plan utracił moc w innych okolicznościach niż wskazane w art. 67 u.z.p., albo gdy plan ten określał przeznaczenie tego terenu jako rolne lub leśne. Jak bowiem wskazano w uchwale NSA z dnia 29 listopada 2010 r., II OPS 1/10 ${ }^{53}$, nie można przyjąć tezy, że decyzja o zgodzie na zmianę przeznaczenia gruntu rolnego lub leśnego na cele nierolnicze i nieleśne dokonuje zmiany przeznaczenia tego gruntu, a to dlatego, że warunkiem nierolniczego i nieleśnego wykorzystania gruntów jest wejście w życie miejscowego planu zagospodarowania przestrzennego określającego przeznaczenie tego terenu jako nierolnicze i nieleśne. W związku z tym omawiana przesłanka wydania decyzji lokalizacyjnej nie zachodzi, gdy dla danego - wymagającego uzyskania zgody, o której mowa art. 7 ust. 2 u.g.r.l. - terenu wydana została zgoda właściwego organu na zmianę przeznaczenia na cele nierolnicze i nieleśne, ale nie wprowadzono stosownych zapisów do miejscowego planu zagospodarowania przestrzennego, który obowiązywał w dniu 1 stycznia 1995 r. i utracił moc obowiązującą na podstawie art. 67 u.z.p.

\section{Podsumowanie i wnioski}

Powyższe rozważania mogą prowadzić do konstatacji, że obowiązujące regulacje normatywne zasadniczo chronią grunty rolne i leśne, a przez to również klimat. W regulacjach ogólnych z tego zakresu przyjęto bowiem zasadę, iż przeznaczenie gruntu rolnego najwyższej przydatności produkcyjnej położonego poza granicami administracyjnymi miasta lub leśnego na cel nierolniczy i nieleśny wymaga uprzedniej zgody właściwego organu. Zauważyć należy jednak, że ustawodawca wprowadził wyjątki w tym zakresie, dopuszczając - przy założeniu spełnienia wskazanych przesłanek określenie zarówno w miejscowym planie zagospodarowania przestrzennego, jak i w decyzji o warunkach zabudowy i zagospodarowania terenu przeznaczenia takiego gruntu na cel nierolniczy i nieleśny. Poza wskazanymi przypadkami ustawodawca dopuścił wydanie opisanej powyżej decyzji lokalizacyjnej, gdy w odniesieniu do gruntu rolnego lub leśnego ustalono już w miejscowym planie zagospodarowania przestrzennego przeznaczenie inne niż rolnicze i leśne, a następnie plan ten - w związku z regulacją ujętą w art. 67 u.z.p. - wygasł z końcem 2002 r. lub 2003 r.

53 LEX nr 621577. 
Wskazać należy również, że dla gruntów wymagających zgody, o której mowa w art. 7 ust. 2 u.g.r.l. może być wydana decyzja określająca warunki zabudowy i zagospodarowania terenu dla przedsięwzięć, które są zgodne z rolnym lub leśnym przeznaczeniem terenu, a więc nie prowadzą do zmiany jego przeznaczenia, a jedynie mają służyć kontynuacji celu, na jaki teren jest przeznaczony, pogłębieniu posiadanej przez niego funkcji ${ }^{54}$. Wskazuje się bowiem, że celem omawianej regulacji jest podkreślenie prawnej ochrony gruntów rolnych i leśnych przed niekontrolowaną zmianą ich przeznaczenia, a nie blokowanie inwestycji służących rolniczemu lub leśnemu wykorzystaniu tych gruntów ${ }^{55}$, co oznacza, że grunty te mogą być zabudowane np. budynkami mieszkalnymi oraz innymi budynkami i urządzeniami służącymi produkcji rolniczej oraz przetwórstwu rolno-spożywczemu. Nadto, zabudowa taka może być przewidziana w miejscowym planie zagospodarowania przestrzennego na obszarach, w odniesieniu do których nie wydano zgody na zmianę przeznaczenia na cel nierolniczy i nieleśny. Wreszcie ustawodawca dopuszcza lokalizowanie na takich gruntach większości inwestycji podlegających regulacjom tzw. specustaw inwestycyjnych.

To wszystko powoduje, że - w świetle obowiązujących regulacji normatywnych grunty rolne i leśne w Polsce mogą podlegać stopniowemu zabudowywaniu. Pewne możliwości przeciwdziałania temu procesowi mają gminy, które w uchwalanych miejscowych planach zagospodarowania przestrzennego mogą - jeśli taka będzie wola rady gminy, czyli organu stanowiącego tej jednostki samorządu terytorialnego - stanowić w odniesieniu do tych gruntów zakaz zabudowy ${ }^{56}$. Decyzje lokalizacyjne są zaś rozstrzygnięciami związanymi, co oznacza, że w przypadku ustalania warunków zabudowy i zagospodarowania terenu na podstawie przepisów u.p.z.p., organ właściwy w sprawie jest zobligowany do zbadania stanu faktycznego m.in. pod kątem przesłanki określonej w art. 61 ust. 1 pkt 4 u.p.z.p., i jeśli w toku tych ustaleń stwierdzi, iż ona obok pozostałych przesłanek ustawowych - zachodzi, musi wydać rozstrzygnięcie pozytywne dla inwestora. Swobody planistycznej pozbawione są również organy właściwe w przedmiocie wydawania decyzji ustalających lokalizację inwestycji w trybie tzw. specustaw inwestycyjnych. Rozstrzygnięcie w tym zakresie zapada bowiem z pominięciem ustaleń miejscowego planu zagospodarowania przestrzennego, nawet jeżeli wyłącza on spod zabudowy grunty rolne i leśne, a nadto zasadniczo z pominięciem przepisów u.g.r.l.

Mając na uwadze powyższe, wskazać należy, że obowiązujące regulacje normatywne stanowiące podstawę dla przeznaczania gruntów pod zabudowę trudno postrzegać jako chroniące klimat. Ustawodawca, dopuszczając stopniową zabudowę gruntów rolnych i leśnych, akceptuje bowiem, że regulowanie zmian klimatycznych może być z każdym rokiem coraz trudniejsze.

\footnotetext{
$\overline{54}$ Zob. wyrok WSA w Warszawie z dnia 1 czerwca 2007 r., IV SA/Wa 598/07, LEX nr 340817; wyrok WSA w Warszawie z dnia 11 sierpnia 2009 r., IV SA/Wa 697/09, LEX nr 553492.

55 Zob. Planowanie i zagospodarowanie przestrzenne. Komentarz..., s. 524.

56 Na temat dopuszczalności wprowadzania ograniczeń w zagospodarowaniu terenu w miejscowym planie zagospodarowania przestrzennego zob. A. Fogel [w:] eadem, W. Federczyk, A. Kosieradzka-Federczyk, Prawo ochrony środowiska w procesie inwestycyjno-budowlanym, Warszawa 2015, s. 92 i n.
} 


\section{Literatura}

Bruyninckx H., Sygnały EEA. Grunty i gleby: w kierunku zrównoważonego gospodarowania tymi niezbędnymi zasobami, https://www.eea.europa.eu/www/pl/publications/sygnaly-eea-2019-grunty-i [dostęp: 12.05.2021].

Bruyninckx H., Sygnały EEA. Życie w zmieniającym się klimacie, https://www.eea.europa.eu/pl/publications/sygnaly-eea-2015-zycie-w [dostęp: 12.05.2021].

Ciechanowicz-McLean J., Prawo ochrony klimatu, Warszawa 2016.

Dobrowolski D., Świat a zmiany klimatyczne, https://globalna.ceo.org.pl/wiedza-o-spoleczenstwie-geografia-biologia/artykuly/swiat-zmiany-klimatyczne [dostęp: 12.05.2021].

Federczyk W., Fogel A., Kosieradzka-Federczyk A., Prawo ochrony środowiska w procesie inwestycyjno-budowlanym, Warszawa 2015.

Instytucje prawa rolnego, red. M. Korzycka, Warszawa 2019.

Kaczor J., Zmiana przeznaczenia gruntów rolnych klas I-III na podstawie art. 7 ust. $2 a$ ustawy o ochronie gruntów rolnych i leśnych, NZS 2017, nr 3.

Leoński Z., Szewczyk M., Kruś M., Prawo zagospodarowania przestrzeni, Warszawa 2019.

Małysa K., Ustalanie warunków zabudowy i zagospodarowania terenu dla gruntów rolnych, Sam. Teryt. 2003, nr 11.

Małysa-Sulińska K., Administracyjnoprawne aspekty inwestycji budowlanych, Warszawa 2012.

Małysa-Sulińska K., Zakres przedmiotowy przedsięwzięć, dla których warunki zabudowy i zagospodarowania terenu określane sq $w$ formie decyzji o ustaleniu lokalizacji inwestycji celu publicznego, "Casus" 2009, nr 53.

Planowanie i zagospodarowanie przestrzenne. Komentarz, red. Z. Niewiadomski, K. Jaroszyński, A. Szmytt, Ł. Złakowski, Warszawa 2011.

Prawo do dobrego samorzq̨u w kontekście realizacji zadań publicznych, red. M. Stec, K. Małysa-Sulińska, Warszawa 2021.

Radecki W., Ustawa o ochronie gruntów rolnych i leśnych. Komentarz, Warszawa 2012.

System administracyjnego prawa procesowego, red. A. Matan, G. Łaszczyca, t. 4, Warszawa 2021.

Szewczyk M., Lokalizacja inwestycji publicznych w świetle nowej ustawy o planowaniu izagospodarowaniu przestrzennym, "Casus” 2003, nr 28.

Unia Europejska wobec wyzwań przeszłości. Aspekty społeczne, gospodarcze i środowiskowe, red.

E. Małuszyńska, P. Idczak, G. Mazur, Poznań 2015.

Ustawa o planowaniu izagospodarowaniu przestrzennym. Komentarz, red. M. Wierzbowski, A. Plucińska-Filipowicz, K. Buliński, A. Despot-Mładanowicz, T. Filipowicz, A. Kosicki, A. Plucińska-Filipowicz, M. Rypina, M. Wincenciak, Warszawa 2016.

\section{Streszczenie}

\section{Katarzyna Małysa-Sulińska}

Klimat a ochrona gruntów rolnych i leśnych przy ustalaniu lokalizacji inwestycji w oparciu o przepisy ogólne na obszarach nieobjętych miejscowym planem zagospodarowania przestrzennego

Jako przyczynę narastających zmian klimatycznych wskazuje się m.in. zabudowywanie coraz większych obszarów, w tym również gruntów rolnych i leśnych. W niniejszym artykule podjęto 
próbę ustalenia, czy obowiązujące w Polsce regulacje normatywne stanowiące podstawę dla przeznaczania terenów pod zabudowę chronią grunty rolne i leśne, a przez to klimat. Ich analiza wykazała, że ustawodawca dopuszcza stopniową zabudowę tych gruntów, co oznacza, że w tym zakresie nie podjęto kroków mających na celu zatrzymanie bądź spowolnienie procesu zmian klimatycznych.

Słowa kluczowe: grunty leśne; grunty rolne; ustalanie przeznaczenia terenu.

\section{Summary}

\section{Katarzyna Małysa-Sulińska}

\section{Climate and Protection of Agricultural and Forest Lands When Determining Investment Project Location Based on General Rules in Areas Not Covered by a Zoning Plan}

The development of larger and larger areas, including agricultural and forest lands, is mentioned as one of the reasons for the growing climate change. This article attempts to determine whether the current Polish normative regulations, which form the basis for allocating land for development, protect agricultural and forest lands and thus the climate. Their analysis demonstrated that the legislator permits gradual development of these lands, which means that no steps have been taken in this respect to stop or slow down the process of climate change.

Keywords: agricultural lands; forest lands; determination of land function. 